Editorial

\title{
Islam, Immigration, and Identity: An Introduction
}

\section{Todd H. Green}

Department of Religion, Luther College, 700 College Drive, Decorah, IA 52101 USA;

E-Mail: greeto02@luther.edu

Received: 1 August 2014 / Accepted: 1 August 2014 /

Published: 8 August 2014

Keywords: Islam; Muslims; Islam and the West; immigration; Islamophobia; Clash of Civilizations; multiculturalism; Sharia

It has been two decades since Samuel P. Huntington, a Harvard political scientist, first published his famous essay, “The Clash of Civilizations?” [1]. In the essay, and later in his book with the same title (minus the question mark) [2], Huntington argues that conflict in the post-Cold War era will be driven largely by irreconcilable cultural and religious differences, particularly in regards to Islam and the West. The conflict between these two civilizations, while not new, is bound to persist in large part because Islam is prone to violence. Much of the global conflict that exists in the modern world, observes Huntington, involves Muslims. It is for this reason that he states so bluntly: "Islam has bloody borders” ([1], p. 35).

The "clash of civilizations" thesis did not originate with Huntington. Bernard Lewis, the prominent historian of Islam and orientalist, had already invoked this language in his own scholarship, most notably in his 1990 article for The Atlantic Monthly, “The Roots of Muslim Rage” [3]. In the article, Lewis explores many possible explanations as to why Muslims have so much hatred for the West. He concludes that Muslims are jealous and humiliated due to the superiority of Western civilization. Western secularism and modernism in particular are the objects of Muslim anger and the reason behind the surge in Islamic fundamentalism in recent history.

Both Huntington and Lewis invoke the very themes that Edward Said describes as the foundation of Orientalism [4]. Both view the West as superior and enlightened, in contrast to the Muslim world (i.e., the Orient), which they portray as monolithic, violent, backwards, and irrational. Conflict is inevitable in light of such profound differences, insist Huntington and Lewis, and yet both scholars maintain that the real source of this conflict lies within Islam. 
After the al-Qaeda attacks of September 11, 2001, the clash of civilizations thesis found ready acceptance on both sides of the Atlantic as politicians, foreign policy advisors, and even some highprofile academics utilized the thesis both as an explanation for those events and more broadly as justification for the global War on Terror. Politicians and journalists also applied the thesis to domestic tensions stemming from the growth in recent decades of Muslim minority communities in the West via migration and immigration. The clash of civilizations narrative has now become the primary framework within which public discourse concerning the presence of the Muslim 'Other' within Western nations takes place. Prominent conflicts from the past few decades, including the Rushdie Affair, the Danish cartoon controversy, and the Ground Zero Islamic Center debate, are frequently explained through this narrative and its underlying assumption that Muslim and Western identities cannot be reconciled.

In this Special Issue, distinguished scholars from Europe and North America, representing diverse disciplinary and methodological approaches, problematize the clash of civilizations narrative by exploring more deeply and richly the intersection of Islam, immigration, and identity in the West. The themes addressed in these articles represent some of the most debated issues among scholars, journalists, and politicians pertaining to the place of Muslims in the West and include multiculturalism, Muslim political representation, Sharia controversies, the reconciliation of Muslim with national identities, racism, gender and sexuality, and Islamophobia. Geographically, the authors address the intersection of Islam, immigration, and identity in Western countries that include Britain, France, Italy, Malta, Spain, Sweden, Canada, and the United States.

What the authors share in common is the desire to shed light on how the growth and increasing visibility of Muslim minority communities in the West has led both Muslim and non-Muslim populations to reflect on and/or reconsider cultural, religious, and national identities in light of the 'Other.' While the authors take seriously the very real tensions that exist between Muslim minority communities and the non-Muslim majorities of Europe and North America, they argue, explicitly or implicitly, that recourse to a clash of civilizations framework to explain these tensions does not do justice to the complex ways in which Muslim and Western identities are negotiated and transformed in light of the historic and contemporary interactions between the two.

I want to thank the journal's Editor-in-Chief, Peter Kaufman, and the journal's managing editor, Jerry Zhang, for their support and guidance in putting first the Special Issue and then the book together. I also want to thank the many peer reviewers who vetted the articles and gave constructive feedback to the authors in this volume. Finally, I want to thank the authors for accepting the invitation to contribute to this Issue. I believe their scholarship reflects important dimensions in the ongoing debates concerning the multifaceted relationship between Islam and the West.

\section{References and Notes}

1. Samuel P. Huntington. “The Clash of Civilizations?” Foreign Affairs 72 (1993): 22-49.

2. Samuel P. Huntington. The Clash of Civilizations and the Remaking of World Order. New York: Simon \& Schuster, 1996. 
3. Bernard Lewis. “The Roots of Muslim Rage.” The Atlantic Monthly, September 1990, 47-60.

4. Edward W. Said. Orientalism. New York: Vintage Books, 1978.

(C) 2014 by the author; licensee MDPI, Basel, Switzerland. This article is an open access article distributed under the terms and conditions of the Creative Commons Attribution license (http://creativecommons.org/licenses/by/3.0/). 